\title{
New records of the Critically Endangered Ganges shark Glyphis gangeticus in Bangladeshi waters: urgent monitoring needed
}

\author{
Alifa Bintha Haque ${ }^{1,2, *}$, Sudipta Arka Das ${ }^{3}$ \\ ${ }^{1}$ Department of Zoology, University of Dhaka, Dhaka 1000, Bangladesh \\ ${ }^{2}$ Department of Zoology, University of Oxford, 11a Mansfield Rd, Oxford OX1 3SZ, UK \\ ${ }^{3}$ Department of Biochemistry and Molecular Biology, University of Dhaka, Dhaka 1000, Bangladesh
}

\begin{abstract}
The different species of elasmobranch found in Bangladeshi fisheries and markets were quantified in a survey between February 2016 and November 2017. This resulted in records of the Critically Endangered Ganges shark Glyphis gangeticus (Müller \& Henle, 1839) in the waters of Bangladesh. Three records from the landing sites and shark processing centres of Cox's Bazar in southeast Bangladesh were identified and confirmed as G. gangeticus by sequencing the expression of the cytochrome $c$ oxidase subunit I (COI) gene and by the morphological identification of 1 individual. These represent the most recent records of this species in Bangladesh in over a decade, and only the second set of records from anywhere within the range of this elusive shark. Capture dates and traders' knowledge of these catches suggest a year-round distribution, indicating a population within the Bay of Bengal and adjacent coastal rivers. Although the species is protected under Bangladeshi law, enforcement of the law is inadequate. Monitoring for this, and other, rare and threatened species at landing sites, rigorous surveys to locate any existing populations, trade regulation, and enforcement of conservation legislation should be considered priorities for effective conservation.
\end{abstract}

KEY WORDS: Bay of Bengal - Marine conservation - DNA barcoding - Distribution - Elasmobranch $\cdot$ Elusive river shark

\section{INTRODUCTION}

The Bay of Bengal harbors a rich community of marine animals (Amaral et al. 2017). However, little is known about the elasmobranchs (sharks and rays) in this region (Hoq et al. 2011) owing to a lack of species-specific research regarding their ecology, biology, habitat, trade and species composition (Fischer et al. 2012). Moreover, the world's largest halophytic mangrove forest, the Sundarbans Reserve Forest (SRF), is located in the west of the Bay of Bengal and is a cradle for many unique species (Gopal \& Chauhan 2006), including threatened and evolutionary distinct species. This is a suitable habitat for river

\footnotetext{
${ }^{*}$ Corresponding author: alifa.haque@du.ac.bd
}

sharks, one of the most enigmatic groups of sharks in the world (Li et al. 2015, White et al. 2015). However, there is a paucity of information on their specific distribution in the coastal areas and tropical rivers.

Three species of river shark have been reported in Bangladesh, 2 of which have been described (Glyphis glyphis and G. gangeticus; Roberts 2006, Hoq et al. 2011), and one of which is still undescribed and genetically distinct (Li et al. 2015, Amaral et al. 2017). This undescribed species, overlapping in its distribution with G. gangeticus (Amaral et al. 2017), is only known to be found in the Gangetic delta (Pal et al. 2014). Within the western Indo-Pacific, the Ganges shark (G. gangeticus) has a widespread but patchy

() The authors 2019. Open Access under Creative Commons by Attribution Licence. Use, distribution and reproduction are unrestricted. Authors and original publication must be credited. 
distribution (Jabado et al. 2018) (Table 1). Identification is based primarily on the jaws because whole individuals have rarely been found and examined. Previously believed to be restricted to freshwater in the Ganges, this species is predominantly euryhaline, with marine records documented by Roberts (2006).

G. gangeticus is characterized by conflicting information spanning from the early 1800s to recent studies. Information varies from it being designated as a species endemic to the freshwater of the Ganges to it being a man-eater (Roberts 2006). While it was mentioned to have been the 'most common' ground shark species in the Bay of Bengal (Roberts 2006), it is also designated as Critically Endangered by the IUCN Red List of Threatened Species (Compagno 2007), mainly because of the continued decline of mature individuals, its restricted range, overfishing, increased human use of rivers, pollution and habitat degradation (Compagno 1997). Moreover, it is only known historically from museum specimens (Compagno 2007), where cryptic similarities to other species and lack of specimen data pose great challenges to accurate morphological identification. Prior to the taxonomic resolution by Li et al. (2015), G. siamensis and $G$. fowlerae were considered to be synonymous to G. gangeticus, further complicating the identification process.

After it was first described in 1839, the species was not recorded between 1867 and 1996, with the 1996 record being unconfirmed (Compagno 2007). However, several specimens of Ganges sharks were reported in 2006 (Roberts 2006) from Bangladesh. Inconsistent monitoring resulted in long intervals between encounters. Hence, monitoring such rare and threatened species requires multiple methods, including market and landing observations, evaluating ecological knowledge of fishers and traders, habitat surveys, and the use of molecular techniques such as DNA barcoding.

Two pieces of regional legislation protect endangered species in the Bay of Bengal and apply to $G$. gangeticus. Since 2001, G. gangeticus has been protected under Schedule I, Part II A of the Indian Wildlife (Protection) Act, 1972, and also under Schedule I of the Wildlife (Conservation and Security) Act, 2012, in Bangladesh. The effectiveness of these regulative measures is limited, for the following reasons. Firstly, effective elasmobranch landing monitoring programs run by government agencies are either absent altogether or highly faulty. This leads to limited knowledge of threatened and data deficient species. Secondly, there is a lack of awareness among fisherfolk and traders about the law and what they should do with protected species. The present study thus aimed to monitor the largest landing site for marine fish, Cox's Bazar, Bangladesh, for 3 mo following the discovery of $G$. gangeticus among the elasmobranch products traded there.

The present study provides an initial understanding of the landing patterns of rare and threatened elasmobranch species in Bangladesh and identifies

Table 1. Summary of historical and recent records of Glyphis gangeticus showing patchy encounter rates after long intervals. TL: total length; -: not known

\begin{tabular}{|c|c|c|c|c|c|}
\hline Specimen & $\begin{array}{c}\text { No. of } \\
\text { specimens }\end{array}$ & $\begin{array}{l}\text { Location of } \\
\text { collection }\end{array}$ & $\begin{array}{l}\text { Time of } \\
\text { collection }\end{array}$ & Reference & Notes \\
\hline $\begin{array}{l}\text { Historical samples } \\
\text { of G. gangeticus }\end{array}$ & 3 & $\begin{array}{l}\text { Lower reaches of the } \\
\text { Ganges-Hooghly } \\
\text { freshwater river system }\end{array}$ & $\begin{array}{l}\text { 19th } \\
\text { century }\end{array}$ & $\begin{array}{l}\text { Compagno (1997), } \\
\text { Roberts (2006) }\end{array}$ & $\begin{array}{l}\text { Preserved in museums } \\
\text { in Paris, Berlin, and India }\end{array}$ \\
\hline G. gangeticus & - & Ganges River & 1996 & Compagno (2007) & After searching for $10 \mathrm{yr}$ \\
\hline $\begin{array}{l}\text { Further confirmation } \\
\text { of G. gangeticus }\end{array}$ & - & $\begin{array}{l}\text { Upstream of Hooghly } \\
\text { River, at Mahishadal }\end{array}$ & - & $\begin{array}{l}\text { Compagno et al. } \\
\text { (2008) }\end{array}$ & By a photograph of the jaw \\
\hline $\begin{array}{l}\text { More recent } \\
\text { encounter } \\
\text { of G. gangeticus }\end{array}$ & Several & $\begin{array}{l}\text { Lower Sundarbans, } \\
\text { south of Khulna, } \\
\text { Bangladesh }\end{array}$ & 2006 & Roberts (2006) & $\begin{array}{l}\text { Identified as a common } \\
\text { shark, contrary to } \\
\text { existing beliefs }\end{array}$ \\
\hline $\begin{array}{l}\text { First record of } \\
\text { G. gangeticus in } \\
\text { the Arabian Sea }\end{array}$ & 1 & Mumbai, India & $\begin{array}{l}\text { Feb } \\
2016\end{array}$ & Jabado et al. (2018) & Female, $266 \mathrm{~cm} \mathrm{TL}$ \\
\hline $\begin{array}{l}\text { First record of } \\
\text { G. gangeticus in } \\
\text { Bangladesh after } \\
\text { more than a decade }\end{array}$ & 3 & $\begin{array}{l}\text { Cox's Bazar, } \\
\text { Bangladesh, } \\
\text { Bay of Bengal }\end{array}$ & $\begin{array}{l}\text { Feb-Nov } \\
2017\end{array}$ & Present study & $\begin{array}{l}\text { Male, } 118.11 \mathrm{~cm} \mathrm{TL} \\
\text { (1 of the } 3 \text { specimens) }\end{array}$ \\
\hline
\end{tabular}


challenges for their conservation. It includes the very first records of G. gangeticus from Bangladeshi waters since 2006. It also tests the usefulness of incorporating local knowledge on trade, seasonality, and perceptions of sharks and shark conservation legislation.

\section{MATERIALS AND METHODS}

\subsection{Sampling site, genetic sampling and analysis}

Cox's Bazar was chosen as a sampling site as it is the largest landing site for marine fish by volume and is a trade hub for elasmobranchs in southeast Bangladesh. The shark landing site $(\mathrm{n}=1)$ and processing centres $(n=6)$ in Cox's Bazar were visited twice a month (Fig. 1) between February 2016 and November 2017. Morphological data on all landed whole elasmobranch species and 20-30 tissue samples of meat, fin, and muscle from jaws and skin were collected randomly from the landing site. Where it was possible to differentiate individuals and individual species, 3 to 10 genetic samples were also collected from different species or body parts; this was to avoid redundancy, i.e. collecting tissue from the same specimen. They were photographed at the processing centres during each field visit. Collected samples were preserved in $98 \%$ ethanol and transported to the laboratory, where they were stored in a freezer at $-20^{\circ} \mathrm{C}$ until analysis. DNA barcoding with cytochrome $c$ oxidase subunit I (COI) was used to confirm the identification of Glyphis gangeticus using the methods of Ward \& Holmes (2007), Ward et al. (2008), Moura et al. (2008) and Naylor et al. (2012). Samples were compared to a genetic database (GenBank) using blasting to match these samples with previously collected, documented and submitted G. gangeticus samples. A family tree with other specimens was then constructed.

\subsection{Morphological measurements}

Morphometric measurements and photographs of 3 Ganges sharks were collected using the methodology of Compagno (2001) for all specimens (S1, S2, and S3). The total length (TL) and mass of 2 specimens (S2 and S3) were estimated from the description of the trader using an informal interview technique (see the Supplement at www.int-res.com/ articles/suppl/n040p065_supp.pdf).

\subsection{Informal interviews}

To quantify local knowledge of native carcharhinid sharks, the fishers and traders were asked to participate in a brief informal interview following the extraction of DNA samples. The interviewees were shown photographs of several species from the order Carcharhiniformes (e.g. Ganges shark, pig eye shark, bull shark, tiger shark, silky shark, spot-tail shark, scalloped hammerhead and winghead shark) to determine whether locals are able to differentiate them.

\section{RESULTS}

\subsection{Morphological identification}

On 13 November 2017, a whole specimen of Glyphis gangeticus (S1) was identified from the Bangladesh Fisheries Development Corporation (BFDC) landing site, Cox's Bazar (Fig. 1). The identification of the specimen (Fig. 2A,B) was based on the combination of the characteristics described in Compagno (2001), Ebert et al. (2013), and Jabado et al. (2018). The specimen was a male and had relatively small eyes; a short, broad and rounded snout; no interdorsal ridge; the 1st dorsal fin originated from the rear ends of the pectoral bases; the 2nd dorsal fin was almost half the height of the 1st dorsal fin; and the anal fin had a deeply notched posterior margin (Table S1 in the Supplement). Additional information on teeth could not be collected as the specimen was removed rapidly by the traders and buyers at the landing site. The specimen was probably a sub-adult given its size $(\mathrm{TL}=118.11 \mathrm{~cm}$; measured over a straight line along the axis of the body from the tip of the snout to the posterior tip of the upper lobe of the caudal fin in its natural condition), and the claspers were not totally calcified as determined by holding the specimen tightly. A summary of the whole individual and the other 2 specimens are given in Table 2 .

During this study, 13 individuals were photographed that were morphologically similar to Ganges sharks (Glyphis spp.). These species were investigated for a better understanding of their occurrence and to minimize the risk of misidentification. However, 2 were proven to be bull sharks and, due to lack of quality photographs and genetic material available, the remaining individuals could not be identified confidently. This demonstrates the challenges of identifying Ganges sharks only from photographs while the researcher is not in the field and when good quality reference photographs are not available. 


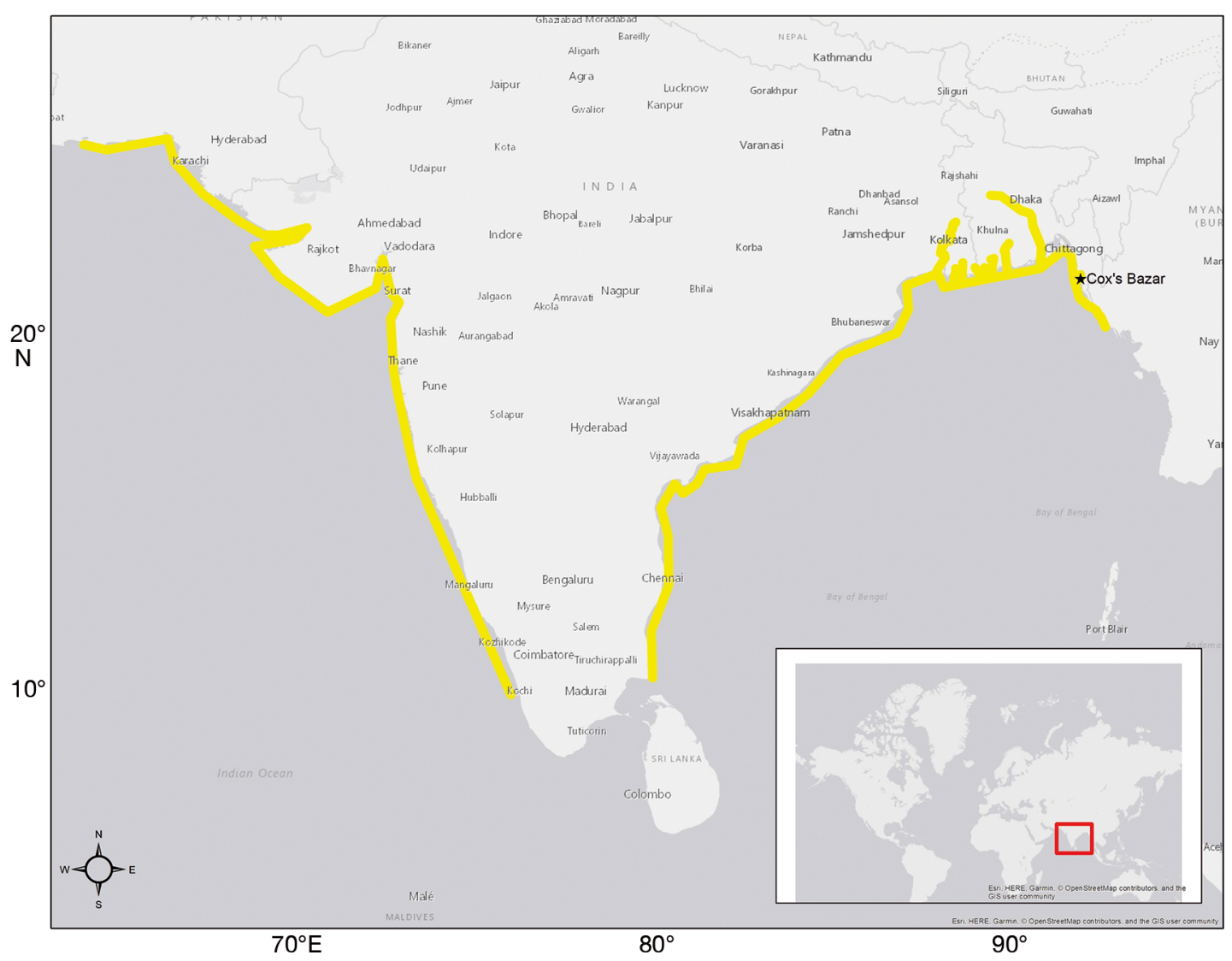

Fig. 1. Area of occurrence of Glyphis ganteticus (inset). Yellow lines indicate the range (extant) according to the IUCN, Jabado et al. (2018), Roberts (2006) and Compagno (2002). Black star: one of the sites (Cox's Bazar) where regular landing monitoring was conducted

\subsection{Identification through DNA barcoding}

The partial COI gene sequence of specimen 1 (GenBank accession number MH841976) was 656 bp in length. It was blasted against sequences in GenBank and there was $100 \%$ pairwise identity of the $G$. gangeticus sequences to GenBank accession number KT698058 (G. gangeticus isolate GN1188 mitochondrion, complete genome; PMID: 26460025). The partial COI gene sequences of specimens 2 (GenBank accession number MH841975) and 3 (MH841977) were also $656 \mathrm{bp}$ in length. There was $99 \%$ pairwise identity of the G. gangeticus sequences to accession number KT698054 (G. gangeticus isolate GN2669 mitochondrion, complete genome; PMID: 26460025) when blasted against sequences in GenBank.

The resultant phylogenetic tree from the neighbour-joining analysis of the COI data derived from the 3 G. gangeticus specimens, together with previously available sequences of other representatives of G. gangeticus, G. siamensis, G. fowlerae, G. garricki and G. glyphis, is shown in Fig. 3. G. siamensis and
G. fowlerae are considered to be synonyms of $G$. gangeticus (Li et al. 2015). The 3 specimens of $G$. gangeticus cluster within the clade of G. gangeticus sequences derived from individuals sampled from various locations on the subcontinent.

\subsection{Insights into catch location, trade, and seasonality}

All 3 specimens were non-discarded bycatch from the Bay of Bengal, Bangladesh region (not more than $40 \mathrm{~m}$ depth) from artisanal fishers using an array of drift gillnets, set-bag nets, trammel nets, and long lines. The fishers target a variety of marine fish, predominantly Ilisha (Hilsa taneolosa, family Clupeidae). Artisanal boats originate from Cox's Bazar and go on to catch fish on a 7- to 12-d trip. These artisanal boats catch fish throughout the coastal waters between 0 and $40 \mathrm{~m}$ depth (Shamsuzzaman et al. 2017) and sometimes beyond. Two of the samples were identified from randomly selected dried and 


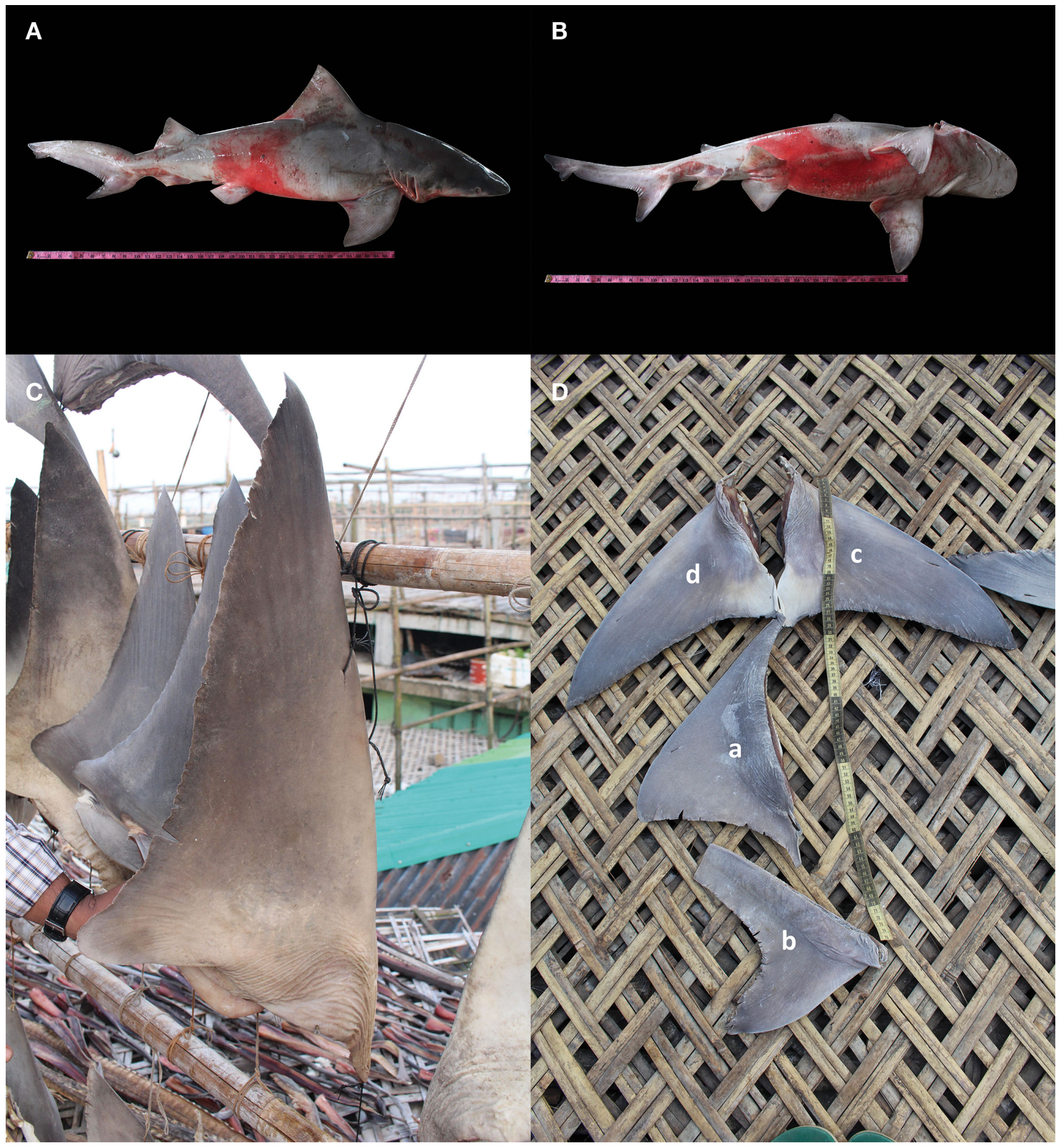

Fig. 2. (A,B) Dorsal and ventral view of specimen 1 (S1) of Glyphis gangeticus, estimated total length $118 \mathrm{~cm}$. (C) Semi-dried pectoral fins of specimen 2 (S2) of G. gangeticus and (D) semi-dried fins of G. gangeticus specimen 3 (S3). Estimated total length $188 \mathrm{~cm}$ : (a) first dorsal fin; (b) lower caudal-fin lobe; (c) left pectoral fin; (d) right pectoral fin; caught from the territorial waters of Bangladesh and landed in Cox's Bazar

semi-dried fin samples in the shark processing centres, where the majority of the dried meat is exported to Myanmar (Haque et al. 2018). Therefore, these samples provide evidence of the existing interna- tional trade in these species. The specimens were collected in the months of February (early summer), April (summer), and November (winter), indicating a nearly year-round catch. 
Table 2. Summary of the 3 Glyphis gangeticus specimens recorded from Cox's Bazar, Bangladesh. TL: total length

\begin{tabular}{|c|c|c|c|c|c|c|}
\hline Specimen & Local name & Location & Date of observation & $\mathrm{TL}(\mathrm{cm})$ & Sex & Part \\
\hline S1 & Bhota, Boli hangor & $\begin{array}{l}\text { BFDC landing site, } \\
\text { Cox's Bazar }\end{array}$ & 13 Nov 2017 & 118.11 & Male & Whole \\
\hline S2 & Unknown & $\begin{array}{c}\text { Shark processing centre, } \\
\text { Cox's Bazar }\end{array}$ & 29 Apr 2017 & Unknown & Unknown & Pectoral fin \\
\hline S3 & Unknown & $\begin{array}{c}\text { Shark processing centre, } \\
\text { Cox's Bazar }\end{array}$ & 13 Feb 2017 & 188 & Unknown & Fin set \\
\hline
\end{tabular}

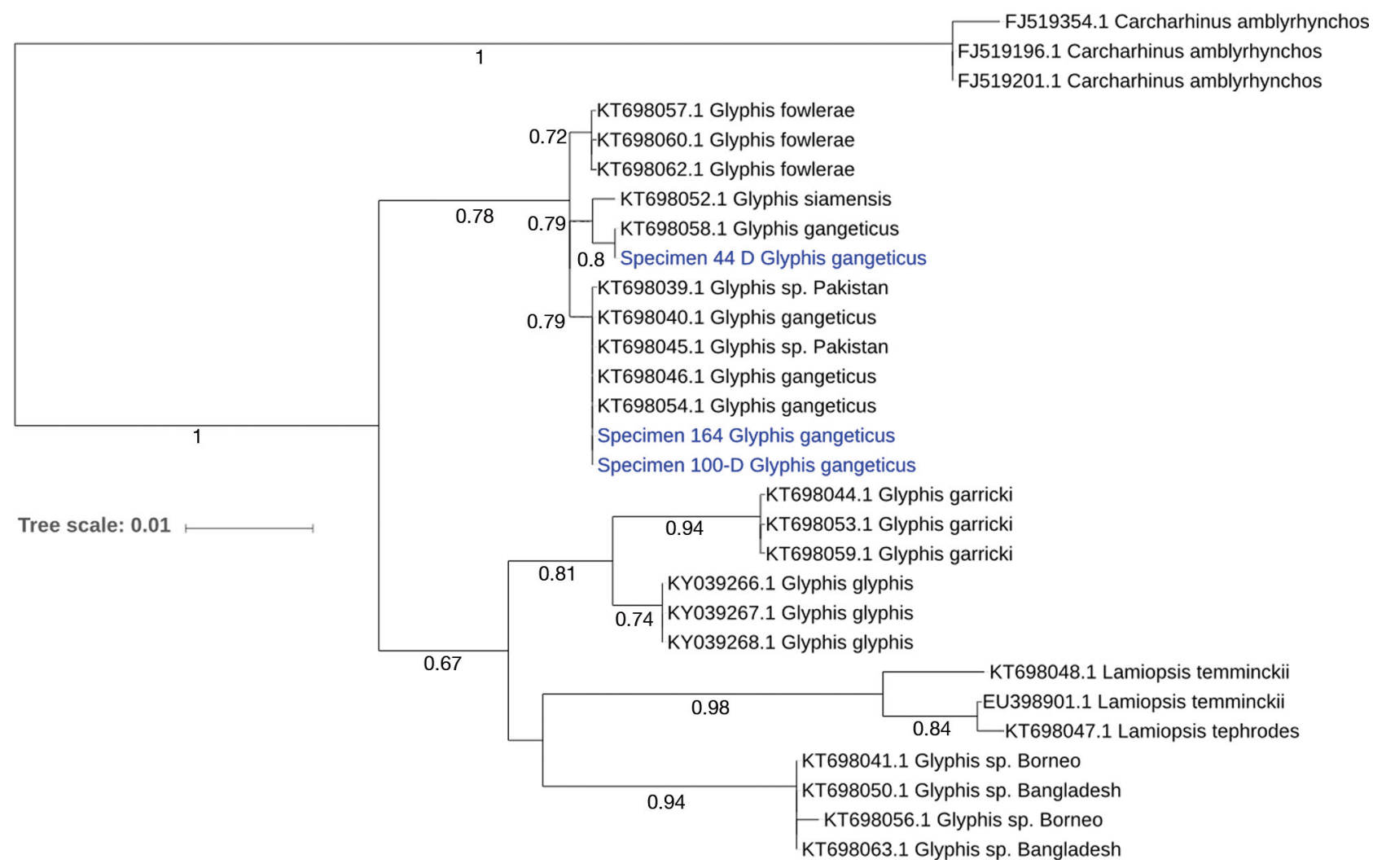

Fig. 3. Molecular species identification using the mitochondrial cytochrome $c$ oxidase subunit I (COI) gene. Neighbour-joining tree of the COI gene (656 bp partial sequence) of specimen 100D, specimen 164, and specimen 44D, and 26 related sequences of Glyphis garricki, G. glyphis, G. gangeticus, and G. fowlerae downloaded from GenBank. Bootstrap values are shown on each branch. The specimens are confirmed as G. gangeticus

\subsection{Identification capacity of locals}

The fishers and traders $(\mathrm{n}=31)$ were asked to identify G. gangeticus when shown photographs of several species from the order Carcharhiniformes. Fishers and traders were asked to differentiate between G. gangeticus and other species of the order Carcharhiniformes. There was no evidence that the fishers and traders (total $\mathrm{n}=31$ ) could differentiate between Carcharhinus leucas and C. amboinensis. They could not differentiate between the 2 river sharks (G. glyphis and G. gangeticus). A total of $87 \%$ of the respondents $(n=27)$ could not differentiate any of these species, whereas $13 \%(n=4)$ could tell that the Ganges shark was a different species from the others. However, they could not specify what the differentiating trait was. The level of identification capacity between fishers and traders did not vary significantly. This result is not conclusive with respect to their ability to identify the Ganges shark as the respondents may have been influenced by the presence of a researcher, biasing their responses to 
these questions. The traders could not elaborate as to the exact locations of their catch. However, they broadly mentioned nearshore catch locations and especially the south-central region of Bangladesh and Sundarbans.

\section{DISCUSSION}

\subsection{The existing G. gangeticus population in Bangladeshi waters}

Glyphis gangeticus is one of the most rarely recorded species of shark in Bangladesh, and records are extremely patchy throughout its range, with no confirmed reports from Bangladesh since 2006. This is due to the rarity of the species and its difficult identification. Therefore, this publication is the first verified report of a G. gangeticus specimen from Bangladesh within its home range in over a decade. There was only one previous recent record from the Arabian Sea (Jabado et al. 2018). This indicates the importance of studying this elusive species more comprehensively within its range. Although the authors acknowledge the limitation of the study due to the small sampling size and the inherent limitations of DNA barcoding in identifying species, the 3 G. gangeticus specimens, one of which was immature, indicate the possible existence of a population in the Ganges Delta and the Bay of Bengal. A more comprehensive survey of elasmobranch species is therefore critical in this region.

\subsection{Challenges of identification}

Identification remains a challenge, as there is a lack of photographic evidence to be used as a reference. Historically, one specimen collected from the Hooghly River in 1967 and preserved by the Zoological Survey of India, Calcutta, was misidentified as Carcharias temmnicki (Lamiopsis temminckii), the broadfin shark. Moreover, Carcharhinus leucas is easily confused with G. gangeticus (Martin 2005) and is sometimes mislabeled as Carcharhinus sp. due to their similar morphology (Compagno 2007). This challenge is also demonstrated by the fishers' and traders' lack of ability to identify G. gangeticus and to confuse it with other species. Diagnostic characteristics are not practical for use by untrained fishers, and would lead to potential misidentifications. Hence, there is a possibility that the anecdotal bull shark reports from many coastal rivers in Bangladesh could be G. gangeticus. This could explain the lack of reports of G. gangeticus in Bangladesh. The present study provides clear, diagnostic photographs suitable for use as future references by researchers and fishers in Bangladesh. Alternative identification methods such as molecular techniques could provide more accurate identification for elusive elasmobranch species.

Using DNA sequence data, only 3 species of Glyphis have been validated (G. gangeticus, G. garricki, and G. glyphis) with one additional species being undescribed (Li et al. 2015). Hence, molecular techniques are recommended for any case of confusion between river shark species until further morphological details are available and incorporated into monitoring studies for species confirmation. Altogether, it plays an important role as a case study to evaluate the significance of a successful monitoring program based on collaboration with local stakeholders, for better knowledge of the distribution of rare and threatened elasmobranchs for priority conservation actions.

\subsection{Conservation implications of this study}

G. gangeticus and G. garricki are assessed as Critically Endangered by the IUCN Red List of Threatened Species (Compagno 2007). Even though knowledge gaps remain regarding the occurrence, habitat preference and distribution of G. gangeticus, the present study identifies the importance of systematic surveys in quantifying enigmatic and data deficient species such as Glyphis spp. in survey-poor areas such as the Bay of Bengal. This study additionally highlights the importance of species-specific monitoring and research in Bangladesh and the adjacent waters to support evidence-based conservation efforts. Further, it confirms the presence, landing in commercial sites, and trade of Ganges sharks in Bangladesh and reveals the challenges in identification, consistent monitoring, and subsequent lack of conservation and research actions.

Historical records, museum specimen locality data, and the latest studies (Roberts 2006, Amaral et al. 2017) suggest that the tidal river systems of Sundarbans and the territorial coastal and marine waters of Bangladesh could still be a stronghold of this species. There is no systematic marine fisheries monitoring by the government or fisheries agencies for elasmobranch catch in Bangladesh, and all catches are lumped as 'sharks, rays and skates' (FRSS 2018). Hence, no species-specific data are available from the national statistics, resulting in a lack of historical 
understanding of the frequency of landing or bycatch trends. Even in the very recent surveys conducted in India, no specimen was recorded until 2017 (Kizhakudan et al. 2015). This lack of records is indicative of either local extirpation in some of its historical range (Jabado et al. 2018), poor identification capacities (Akhilesh et al. 2014), or small population size. This indicates a data gap in information needed for effective conservation measures.

To collect more species-specific data, a long-term monitoring plan should be implemented and institutionalized within the Bangladesh Fisheries Development Corporation, the governing body currently responsible for the accounting of marine landing in commercial sites. A 3-pronged method of monitoring is recommended.

First, a long-term study at landing sites including morphological identification using reference photographs (including teeth), morphometries, and genetic identification is necessary to understand the annual landings and bycatch trends and to identify additional species, as suggested by Li et al. (2015). This will resolve the taxonomic challenges posed by these species as well.

Second, regular monitoring of the shark processing centres in collaboration with traders is needed to complement the landing site study and achieve a full understanding of catch and trade.

Third, a thorough socio-ecological study with fishers in the coastal waters to understand the catch trend and identify critical habitats is recommended to evaluate any existing populations for evidencebased conservation. Environmental DNA (eDNA) studies are also recommended to identify the presence of elusive elasmobranchs in Sundarbans.

The observed specimens of $G$. gangeticus may have been caught along the coast of the Sundarbans, which would indicate that this is possibly a critical habitat for the species. The specimens may also have travelled long distances from the adjacent waters of Myanmar, India, Pakistan or Borneo, as marine dispersal of thousands of kilometers has been suggested by current gene flow between populations (Li et al. 2015). As this species uses rivers and coastal areas for nursery grounds and individuals have been recorded from Sundarbans previously (Martin 2005, Roberts 2006, Pillans et al. 2010, White et al. 2015, Feutry et al. 2014), there is a need for transboundary efforts with a special emphasis on Sundarbans. Moreover, G. gangeticus is susceptible to the effects of intensification of anthropogenic modification, habitat degradation, and overexploitation (Jabado et al. 2018). Imperilment of the Sundarbans (Islam \& Wahab
2005) has a serious potential impact in restricting the critical habitat for Glyphis spp. within Bangladeshi waters, while existing trade will further affect the population (Haque et al. 2018). More than 69000 boats deploying more than 183707 nets are registered and in operation (FRSS 2018) alongside a high level of illegal, unreported, and unregulated (IUU) fishing, all of which are contributing to continued elasmobranch bycatch in this area (Shamsuzzaman et al. 2017). Due to a possible overlap of the habitats of these exploited marine fish and of G. gangeticus, and the high fishing pressure, it is probable that the juveniles have been taken as bycatch in the past. However, the fishers now retain the catch as there are markets and demand for these species (Haque et al. 2018, A. B. Haque unpubl.). The specimens reported in this study were all caught by artisanal fishers and all entered into an existing trade of elasmobranch species, almost entirely targeting an international market (Haque et al. 2018). Management measures, which should urgently prioritize rare and threatened species as flagship species are therefore mandatory.

\section{CONCLUSIONS}

Given the Critically Endangered status and rarity of encounters with Glyphis gangeticus, this documentation from Bangladesh is important for speciesspecific monitoring and management, as well as for building a better understanding of its distribution within its range. Understanding the population size in the Bay of Bengal and the adjacent waters and the identification of any critical habitats can guide management regimes. It is also important to incorporate the ecological knowledge of fishers into the monitoring program and to create awareness through involvement in the management efforts. The authors recommend focused research efforts to identify the number of G. gangeticus that are landed annually, the presence of any critical habitat and any existing populations, key sites where trade regulations can be enforced, and a thorough taxonomic study to resolve all identification issues.

Acknowledgements. The authors are grateful to the Biotechnology Research Centre, the University of Dhaka, for partially funding the genetic work. The authors also thank Dr. Peter Kyne and Scott Trageser from the Creative Conservation Alliance for reviewing the manuscript and providing valuable comments, and the International Section Editing Service of the American Fisheries Society for help with editing an earlier version of the manuscript. The authors acknowledge Hasan Arif Rahman for help with mapping. 


\section{LITERATURE CITED}

Akhilesh KV, Bineesh KK, Gopalakrishnan A, Jena JK, Basheer VS, Pillai NGK (2014) Checklist of chondrichthyans in Indian waters. J Mar Biol Assoc India 56:109-120

Amaral AR, Smith BD, Mansur RM, Brownell RL, Rosenbaum HC (2017) Oceanographic drivers of population differentiation in Indo-Pacific bottlenose (Tursiops aduncus) and humpback (Sousa spp.) dolphins of the northern Bay of Bengal. Conserv Genet 18:371-381

Compagno LJ (1997) Threatened fishes of the world: Glyphis gangeticus (Müller \& Henle, 1839) (Carcharhinidae). Environ Biol Fishes 49:400

Compagno LJV (2001) Sharks of the world: an annotated and illustrated catalogue of shark species known to date, Vol 2. Bullhead, mackerel and carpet sharks (Heterdontiformes, Lamniformes and Orectolobiformes). Food and Agricultural Organization, Rome

Compagno LJV (2007) Glyphis gangeticus. The IUCN Red List of Threatened Species: e.T9281A12978210. http:// dx.doi.org/10.2305/IUCN.UK.2007.RLTS.T9281A129782 10.en

Compagno LJ, White WT, Last PR (2008) Glyphis garricki sp. nov., a new species of river shark (Carcharhiniformes: Carcharhinidae) from northern Australia and Papua New Guinea, with a redescription of Glyphis glyphis (Müller \& Henle, 1839). In: Last PR: White WT, Pogonoski JJ (eds) Descriptions of new Australian chondrichthyans. CSIRO marine and atmospheric research paper 22, CSIRO Hobart, p 203-225

Ebert D, Fowler S, Compagno L (2013) Sharks of the world. Wild Nature Press, Plymouth

Feutry P, Kyne PM, Pillans RD, Chen X, Naylor GJP, Grewe PM (2014) Mitogenomics of the speartooth shark challenges ten years of control region sequencing. BMC Evol Biol 14:232

Fischer J, Erikstein K, D'Offay B, Barone M, Guggisberg S (2012) Review of the Implementation of the International Plan of Action for the Conservation and Management of Sharks. FAO Fisheries and Aquaculture Circular No. 1076. FAO, Rome

FRSS (Fisheries Resources Survey System) (2018) Yearbook of fisheries statistics of Bangladesh, Vol 35. Department of Fisheries, Dhaka

Gopal B, Chauhan M (2006) Biodiversity and its conservation in the Sundarban mangrove ecosystem. Aquat Sci 68:338-354

Haque AB, Biswas A, Latifa GA (2018) Observations of shark and ray products in the processing centres of Bangladesh, trade in CITES species and conservation need. Traffic Bull 30:6-14

Hoq ME, Haroon AY, Hussain MG (eds) (2011) Shark fisheries in the Bay of Bengal, Bangladesh: status and potentialities. Support to sustainable management of the BOBLME Pro-

Editorial responsibility: Austin Gallagher,

Herndon, Virginia, USA ject, Bangladesh Fisheries Research Institute

Islam MS, Wahab MA (2005) A review on the present status and management of mangrove wetland habitat resources in Bangladesh with emphasis on mangrove fisheries and aquaculture. Hydrobiologia 542:165-190

Jabado RW, Kyne PM, Nazareth E, Sutaria DN (2018) A rare contemporary record of the Critically Endangered Ganges shark Glyphis gangeticus. J Fish Biol 92:1663-1669

Kizhakudan SJ, Zacharia PU, Thomas S, Vivekanandan E, Muktha M (2015) Guidance on National Plan of Action for Sharks in India. In: CMFRI Marine Fisheries Policy Series 2. Indian Council of Agricultural Research, Kochi. www. fao.org/ipoa-sharks/tools/ipoa-sharks-documents/en/

* Li C, Corrigan S, Yang L, Straube N and others (2015) DNA capture reveals transoceanic gene flow in endangered river sharks. Proc Natl Acad Sci USA 112:13302-13307

* Martin RA (2005) Conservation of freshwater and euryhaline elasmobranchs: a review. J Mar Biol Assoc UK 85: 1049-1074

* Moura T, Silva MC, Figueiredo I, Neves A, Muñoz PD, Coelho MM, Gordo LS (2008) Molecular barcoding of north-east Atlantic deep-water sharks: species identification and application to fisheries management and conservation. Mar Freshw Res 59:214-223

*Naylor GJ, Caira JN, Jensen K, Rosana KAM, White WT, Last PR (2012) A DNA sequence-based approach to the identification of shark and ray species and its implications for global elasmobranch diversity and parasitology. Bull Am Mus Nat Hist 367:1-262

Pal M, Kar S, Mishra SS (2014) An overview of the fishes of Indian Sundarbans and their conservation status. J Environ Sociobiol 11:171-186

* Pillans RD, Stevens JD, Kyne PM, Salini J (2010) Observations on the distribution, biology, short-term movements and habitat requirements of river sharks Glyphis spp. in northern Australia. Endang Species Res 10:321-332

Roberts TR (2006) Rediscovery of Glyphis gangeticus: debunking the mythology of the supposed 'Gangetic freshwater shark'. Nat Hist Bull Siam Soc 54:261-278

* Shamsuzzaman MM, Xiangmin X, Ming Y, Tania NJ (2017) Towards sustainable development of coastal fisheries resources in Bangladesh: an analysis of the legal and institutional framework. Turk J Fish Aquat Sci 17:833-841

Ward RD, Holmes BH (2007) An analysis of nucleotide and amino acid variability in the barcode region of cytochrome $c$ oxidase I ( $\operatorname{cox} 1)$ in fishes. Mol Ecol Notes 7: 899-907

* Ward RD, Holmes BH, White WT, Last PR (2008) DNA barcoding Australasian chondrichthyans: results and potential uses in conservation. Mar Freshw Res 59:57-71

White WT, Appleyard SA, Sabub B, Kyne PM and others (2015) Rediscovery of the threatened river sharks, Glyphis garricki and G. glyphis, in Papua New Guinea. PLOS ONE 10:e0140075

Submitted: November 2, 2018 ; Accepted: August 10, 2019

Proofs received from author(s): October 5, 2019 